\title{
Intravenous iron-dextran: studies on unsaturated iron-binding capacity
}

\author{
J. S. G. COX, G. F. MOSS, I. BREMNER, ${ }^{1}$ AND JANET REASON \\ From Fisons Pharmaceuticals Limited, Holmes Chapel, Cheshire
}

SYNOPSIS A method is described for measuring the plasma unsaturated iron-binding capacity in the presence of very high concentrations of iron as iron-dextran. The procedure utilizes ${ }^{59} \mathrm{Fe}$ to label the apotransferrin with subsequent separation of ionic iron from transferrin-bound iron on an ion exchange or Sephadex G.25 column.

The unsaturated iron-binding capacity has been measured in rabbits and dogs after intravenous injection of iron-dextran and in human subjects after total dose infusion of iron-dextran. No evidence of saturation of the unsaturated iron-binding capacity was found even when the plasma iron values were greater than $40,000 \mu \mathrm{g} \mathrm{Fe} / 100 \mathrm{ml}$.

The treatment of iron-deficiency anaemia by a single intravenous infusion or injection of the total iron requirements in the form of iron-dextran is now an established technique. It has been described by several authors (Basu, 1963; Bonnar, 1965; Marchasin and Wallerstein, 1964; Dawson, Goldthorp, and Spencer, 1965) and is generally called 'total dose infusion' (TDI).

It is essential that when any iron preparation is introduced into the bloodstream in such quantities (2-3 $\mathrm{g}$ as $\mathrm{Fe})$ no large amounts of ionic iron should be precipitated or released. There is no precipitation of iron from iron-dextran (Imferon ${ }^{2}$ ) over a wide $p \mathrm{H}$ range in plasma and none of the proteins at iron concentrations of up to $5 \%$ (Golberg, 1958). The slow clearance over several days of iron-dextran from the bloodstream after TDI gives an indication of its stability in blood (Marchasin and Wallerstein, 1964).

It has been shown in studies in vitro (Fielding and Smith, 1963) that at high concentrations of iron-dextran haemolysis of red blood cells can take place. They attributed this to the presence of ionic iron and calculated that around $0.3 \%$ of the total iron was in this uncomplexed state. Using polarographic and electrophoretic techniques it has been demonstrated that at $p \mathrm{H} 5 \cdot 6,1$ to $2 \%$ of the total iron in iron-dextran is present in the ferrous state,

\footnotetext{
'Present address: Nutritional Biochemistry Department, Rowett Research Institute, Bucksburn, Aberdeenshire.

${ }^{2}$ Fisons Pharmaceuticals Ltd.

Received for publication 6 March 1968.
}

probably as a loosely bound complex and in equilibrium, with most of the remaining iron itself bound in the ferric form (Cox, King, and Reynolds, 1965).

Although the clinical evidence of lack of toxic effects suggested that the plasma iron-binding capacity was not saturated during TDI, it was thought that transferrin might very readily complex with the ionic iron, thus destroying this equilibrium and resulting in a reduction in the unsaturated ironbinding capacity. Using a combination of isotopic and chromatographic techniques, the changes which occur in the plasma unsaturated iron-binding capacity in the presence of large amounts of irondextran have been determined.

\section{METHODS}

Plasma iron was determined by the method of Kok and Wild (1960) with the modifications suggested by Marchasin and Wallerstein (1964). Plasma unsaturated iron-binding capacity determinations were made by a modification of the method of Birdsall, Kok, and Wild (1965). The general procedure was as published in that paper, but it was found necessary to remove the excess unbound ${ }^{59} \mathrm{Fe}$ ammonium citrate which was added to the plasma sample by absorption on a small column $(5 \times 1 \mathrm{~cm})$ of Amberlite IRA-400 resin. The transferrin bound ${ }^{59} \mathrm{Fe}$ was eluted from the column with barbiturate buffer $(p H 7 \cdot 5)$ and the activity of the eluate $(25 \mathrm{ml})$ was determined in a sodium iodide, well-type, gamma scintillation counter.

Determinations of the unsaturated iron-binding capacity were also made by the method of Barber, Dempster, and Anderson (1963) which involves the separation of bound and unbound ${ }^{59} \mathrm{Fe}$ by gel filtration. 
The two methods gave results which were in good agreement.

EFFECT OF IRON-DEXTRAN ON PLASMA UNSATURATED IRONBINDING CAPACITY in vitro Iron-dextran was added to normal plasma samples from rabbits, dogs, and human subjects to give an iron concentration equivalent to $37,500 \mu \mathrm{g} \mathrm{Fe} / 100 \mathrm{ml}$. The samples were incubated at $37^{\circ} \mathrm{C}$ for 10 minutes. The unsaturated iron-binding capacity was measured for each sample before the addition of iron-dextran and after 10 minutes' incubation with iron-dextran (Table I).

EFFECT OF IRON-DEXTRAN ON PLASMA UNSATURATED IRONBINDING CAPACITY IN VIVO The changes in plasma iron concentrations and unsaturated iron-binding capacity were followed in vivo in rabbits, dogs, and human subjects. Blood samples were obtained by venepuncture using $20 \mathrm{ml}$ plastic disposable syringes. Samples were heparinized immediately and plasma was separated by centrifugation. Plasma iron levels and unsaturated iron-binding capacity were determined for each sample.

Control blood samples $(5 \mathrm{ml})$ were taken from the ear veins of four Dutch black and white rabbits (two male and two female) before the injection of iron-dextran $(20 \mathrm{mg} \mathrm{Fe} / \mathrm{kg}$ ) into the ear vein. No attempt was made to duplicate the slow intravenous infusion techniques employed clinically. Further blood samples $(5 \mathrm{ml})$ were taken from the ear veins at intervals after injection, as shown in Table II.

Normal blood samples $(5 \mathrm{ml})$ were taken by venepuncture from two male and two female beagle dogs. Iron-dextran was then injected intravenously $(25 \mathrm{mg}$ $\mathrm{Fe} / \mathrm{kg}$ ) and blood samples were taken at intervals after injection, as shown in Tables III and V.

The values for unsaturated iron-binding capacity were followed in pregnant women given iron-dextran TDI. The women were admitted to hospital on the morning of the infusion. The infusion lasted approximately six hours, and they were allowed to return home one hour after the termination of the infusion. Normal blood samples were taken by venepuncture before the infusion. The volume of iron-dextran to be infused, as determined by the state of iron deficiency, was diluted in a volume of 1 litre of $0.9 \%$ saline. This solution was given as a slow intravenous drip; during the first 15 minutes the infusion was limited to a rate of 15 drops/ minute. After this period, the rate was increased to 40 drops/minute. This standard precaution was taken to minimize any reaction which might occur. Blood samples were taken at intervals after the start of the infusion, as shown in Table IV.

\section{RESULTS}

The results of experiments in vitro performed on several samples of rabbit, dog, and human plasma are given in Table $I$. In both rabbit and dog, the mean of five different plasma samples showed a very slight increase in unsaturated iron-binding capacity after incubation with iron-dextran over the normal
TABLE I

\begin{tabular}{|c|c|c|c|c|c|c|}
\hline EFFECT & OF IROI & EXTRA & & PLASMA & UNSA & \\
\hline & IRO & 3 & CAI & $Y$ in $v$ & tro & \\
\hline Sample & Rabbit & & Dog & & Human & ubject \\
\hline & $\begin{array}{l}\text { Normal } \\
\text { Value }\end{array}$ & $\begin{array}{l}\text { With } \\
\text { Iron- } \\
\text { dextran }\end{array}$ & $\begin{array}{l}\text { Normal } \\
\text { Value }\end{array}$ & $\begin{array}{l}\text { With } \\
\text { Iron- } \\
\text { dextran }\end{array}$ & $\begin{array}{l}\text { Normal } \\
\text { Value }\end{array}$ & $\begin{array}{l}\text { With } \\
\text { Iron- } \\
\text { dextran }\end{array}$ \\
\hline $\begin{array}{l}1 \\
2 \\
3 \\
4 \\
5\end{array}$ & $\begin{array}{l}175 \\
125 \\
125 \\
105 \\
320\end{array}$ & $\begin{array}{r}230 \\
150 \\
85 \\
95 \\
375\end{array}$ & $\begin{array}{l}210 \\
200 \\
315 \\
310 \\
315\end{array}$ & $\begin{array}{l}255 \\
190 \\
280 \\
300 \\
375\end{array}$ & $\begin{array}{l}215 \\
331 \\
267\end{array}$ & $\begin{array}{l}111 \\
177 \\
171\end{array}$ \\
\hline Mean & 170 & 187 & 270 & 280 & 271 & 153 \\
\hline
\end{tabular}

Iron-dextran was added to give a final concentration of iron equivalent $\frac{\overline{0}}{0}$ to $37,500 \mu \mathrm{g} / 100 \mathrm{ml}$. Values expressed as $\mu \mathrm{g} \mathrm{Fe} / 100 \mathrm{ml}$ plasma.

plasma value. The value for the rabbits rose from 170 to $187 \mu \mathrm{g} \mathrm{Fe} / 100 \mathrm{ml}$ and in the dog from 270 ב to $280 \mu \mathrm{g} \mathrm{Fe} / 100 \mathrm{ml}$.

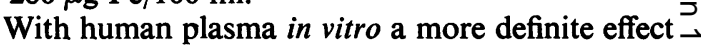
on the unsaturated iron-binding capacity occurred $\mathcal{D}_{\mathcal{D}}$ when iron-dextran was added. In the three samples studied, there was an appreciable fall on average $\frac{\mathbb{D}}{3}$ from 271 to $153 \mu \mathrm{g} \mathrm{Fe} / 100 \mathrm{ml}$.

The effects of intravenous iron-dextran on the unsaturated iron-binding capacity in experiments $\vec{\varphi}$ in vivo in rabbits were variable, as shown by Table II. There was a slight rise immediately after injection $\square$ of iron-dextran and, although the value fluctuated slightly over the six-hour period of study, it never deviated by any large amount from the preinjection value. Samples taken 24,48 , and 72 hours after the $\frac{\circ}{\Phi}$ injection had values for unsaturated iron-binding capacity of approximately half the original normal value.

\section{TABLE II}

EFFECT OF INTRAVENOUS IRON-DEXTRAN INJECTION ON? PLASMA UNSATURATED IRON-BINDING CAPACITY IN RABBITS

Animal Time after Injection (Hours)

No. $\quad \begin{array}{llllllllll} & 0 & 0.5 & 1 & 2 & 4 & 6 & 24 & 48 & 72\end{array}$

\begin{tabular}{llllllllll}
\hline 1 & 230 & 175 & 160 & 100 & 80 & 195 & 70 & 185 & 140
\end{tabular}

\begin{tabular}{|c|c|c|c|c|c|c|c|c|}
\hline $\begin{array}{l}1 \\
2 \\
3 \\
4\end{array}$ & $\begin{array}{r}230 \\
300 \\
100 \\
50\end{array}$ & $\begin{array}{l}175 \\
325 \\
170 \\
220\end{array}$ & $\begin{array}{l}160 \\
315 \\
125 \\
245\end{array}$ & $\begin{array}{l}100 \\
290 \\
135 \\
200\end{array}$ & $\begin{array}{r}80 \\
260 \\
115 \\
150\end{array}$ & $\begin{array}{l}195 \\
240 \\
155 \\
100\end{array}$ & $\begin{array}{r}70 \\
150 \\
55 \\
50\end{array}$ & $\begin{array}{l}50 \\
50\end{array}$ \\
\hline Gean & 170 & 223 & 211 & 206 & 151 & 222 & 81 & 95 \\
\hline
\end{tabular}

Iron-dextran was injected into rabbits at a dose level of $20 \mathrm{mg} \mathrm{Fe} / \mathbf{k g}$. Plasma unsaturated iron-binding capacity expressed as $\mu \mathrm{g} \mathrm{Fe} / 100 \mathrm{mg}$ plasma.

The values for unsaturated iron-binding capacity in dogs after injection of iron-dextran are shown $\frac{\bar{C}}{\bar{C}}$ in Table III. There was an immediate fall in unsaturated iron-binding capacity to a value approximately $70 \%$ of the original value. After this initialo fall, the unsaturated iron-binding capacity remained $\overparen{Q}$ constant for the next six hours. By 24 hours after $\stackrel{\mathbb{D}}{\circ}$ 
the injection, the unsaturated iron-binding capacity had returned to a value approaching the preinjection level and at 48 hours had reached a value slightly in excess of it.

\section{TABLE III}

EFFECT OF INTRAVENOUS IRON-DEXTRAN INJECTION ON PLASMA UNSATURATED IRON-BINDING CAPACITY IN DOGS

Dog No. Time after Injection (Hours)

\begin{tabular}{clllllllll} 
& 0 & $0 \cdot 25$ & 0.5 & 1 & 2 & 4 & \multicolumn{1}{l}{6} & 24 & 48 \\
\hline 1 & 307 & 184 & 175 & 226 & 142 & 169 & 125 & 322 & 308 \\
2 & 193 & 167 & 261 & & 147 & 169 & 145 & 90 & \\
3 & 183 & 145 & 206 & 127 & 159 & 166 & 112 & 226 & 249 \\
4 & 269 & 169 & 128 & 202 & 170 & 167 & 135 & 149 & 242 \\
Mean & 238 & 166 & 193 & 185 & 155 & 168 & 129 & 197 & 266
\end{tabular}

Dose injected $25 \mathrm{mg} \mathrm{Fe} / \mathrm{kg}$. Plasma unsaturated iron-binding capacity expressed as $\mu \mathrm{g} \mathrm{Fe} / 100 \mathrm{ml}$.

Values in human patients are given in Table IV. Unlike the previous animal studies, the iron-dextran was being infused over the whole six-hour period of study and the unsaturated iron-binding capacity was consequently being studied against a gradually rising plasma iron value. The greatest variations were a fall from preinfusion values of $360 \mu \mathrm{g}$ $\mathrm{Fe} / 100 \mathrm{ml}$ to a value of $144 \mu \mathrm{g} \mathrm{Fe} / 100 \mathrm{ml}$ and a rise from the preinfusion value of $344 \mu \mathrm{g} \mathrm{Fe} / 100 \mathrm{ml}$ to $555 \mu \mathrm{g} \mathrm{Fe} / 100 \mathrm{ml}$ during the first half of the infusion. By the end of the infusion, when approximately $2 \mathrm{~g}$ of iron had been given, the lowest value was $167 \mu \mathrm{g} \mathrm{Fe} / 100 \mathrm{ml}$. Plasma unsaturated ironbinding capacity in human beings was not measured at 24,48 , or 72 hours as was the case in the animal studies. The six-hour period of study was the time a patient was kept in hospital for the iron-dextran infusion.

Table $\mathrm{V}$ shows the plasma iron values after intravenous iron-dextran injections in the rabbit and dog. In both species the plasma iron values, immediately following the injection, were of the order of $45,000 \mu \mathrm{g} \mathrm{Fe} / 100 \mathrm{ml}$ and during the following six hours remained greater than $13,000 \mu \mathrm{g}$ $\mathrm{Fe} / 100 \mathrm{ml}$. The plasma iron levels in the dog had returned to near physiological values 24 hours after the injection. In the rabbit, however, at 48 hours after the injection, the plasma iron value was still $1,000 \mu \mathrm{g} \mathrm{Fe} / 100 \mathrm{ml}$. It was not until 96 hours after the injection that physiological values were attained.

Figure 1 shows the plasma iron levels over a period of 16 days after intravenous injection of iron-dextran in human subjects, dogs, and rabbits. In the human subject, the iron-dextran remained in the circulation and maintained a high plasma iron value for a much longer period than in the dog or the rabbit. It was not until 16 days after the injection that the plasma iron levels approached physiological values again.

\section{DISCUSSION}

In view of the 'ionic' iron content of iron-dextran,

TABLE IV

EFFECT OF IRON-DEXTRAN INFUSION ON PLASMA UNSATURATED IRON-BINDING CAPACITY IN PREGNANT WOMEN

\begin{tabular}{|c|c|c|c|c|c|c|c|c|c|c|}
\hline \multirow[t]{2}{*}{ Case No. } & \multirow[t]{2}{*}{ Initials } & \multirow{2}{*}{$\begin{array}{l}\text { Vol. } \\
\text { Iron-dextran } \\
\text { Infused }\end{array}$} & \multicolumn{8}{|c|}{ Time after Start of Infusion (Hours) } \\
\hline & & & 0 & $0 \cdot 5$ & 1 & 2 & 3 & 4 & 5 & 6 \\
\hline \multirow{10}{*}{$\begin{array}{l}1 \\
2 \\
3 \\
4 \\
5 \\
6 \\
7 \\
8 \\
9\end{array}$} & S.K. & 44 & 446 & 471 & 490 & 538 & 535 & 525 & 529 & \\
\hline & N.E. & 36 & 461 & 483 & 480 & 465 & 440 & 409 & 305 & 167 \\
\hline & S.L. & 41 & 393 & 385 & 375 & 370 & 380 & 388 & 325 & 259 \\
\hline & B.A. & 40 & 316 & 324 & 306 & 285 & 315 & 349 & 350 & 360 \\
\hline & M.I. & 45 & 362 & 325 & 292 & 249 & 285 & 325 & 340 & 360 \\
\hline & E.D. & 38 & 304 & 320 & 348 & 340 & 355 & 400 & 445 & 487 \\
\hline & W.A. & 38 & 344 & 386 & 385 & 500 & 540 & 405 & 478 & 546 \\
\hline & A.B. & 40 & 360 & 385 & 373 & 144 & 167 & 190 & 225 & 239 \\
\hline & O.S. & 35 & 562 & 520 & 524 & 449 & 390 & 333 & 275 & 217 \\
\hline & & $39 \cdot 7$ & $\begin{array}{c}394 \\
\pm 82 \cdot 3\end{array}$ & $\begin{array}{c}400 \\
\pm 74.8\end{array}$ & $\begin{array}{c}398 \\
\pm 82.7\end{array}$ & $\begin{array}{c}371 \\
\pm 129 \cdot 3\end{array}$ & $\begin{array}{r}380 \\
+118.6\end{array}$ & $\begin{array}{c}370 \\
\pm 98.6\end{array}$ & $\begin{array}{c}365 \\
\pm 99.9\end{array}$ & $\begin{array}{c}336 \\
\pm 136.3\end{array}$ \\
\hline
\end{tabular}

Plasma unsaturated iron-binding capacity expressed as $\mu \mathrm{g} \mathrm{Fe} / 100 \mathrm{ml}$.

TABLE V

PLASMA IRON DECAY AFTER INTRAVENOUS INJECTION OF IRON-DEXTRAN

Time after Injection (Hours)

\begin{tabular}{|c|c|c|c|c|c|c|c|c|}
\hline & 0.25 & 0.5 & 1 & 2 & 4 & 6 & 24 & 48 \\
\hline $\begin{array}{l}\operatorname{Dog}^{1} \\
\text { Rabbit }^{2}\end{array}$ & $\begin{array}{l}45,150 \\
43,000\end{array}$ & $\begin{array}{l}44,250 \\
36,500\end{array}$ & $\begin{array}{l}38,000 \\
33,200\end{array}$ & $\begin{array}{l}32,300 \\
30,850\end{array}$ & $\begin{array}{l}24,000 \\
27,200\end{array}$ & $\begin{array}{l}18,650 \\
18,400\end{array}$ & $\begin{array}{r}261 \\
2,100\end{array}$ & $\begin{array}{r}121 \\
1,000\end{array}$ \\
\hline
\end{tabular}

${ }^{1} \mathrm{Dog}$, dose $25 \mathrm{mg} \mathrm{Fe} / \mathrm{kg}$.

${ }^{2}$ Rabbits, dose $20 \mathrm{mg} \mathrm{Fe} / \mathbf{k g}$. 


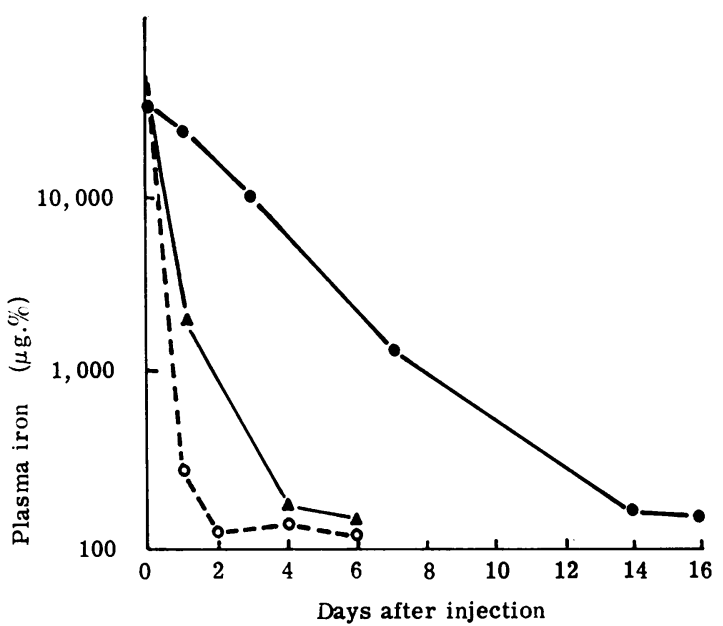

FIG. 1. The decay in plasma iron levels after intravenous injection of iron-dextran.

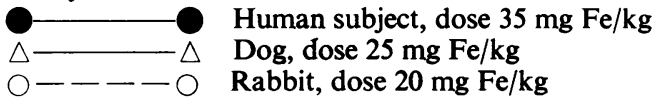

probably present in the ferrous state, it was possible that some saturation of the unsaturated iron-binding capacity would be found in the presence of the very high concentrations of iron in the plasma after total dose infusion. Levels of iron of between 40,000 and $50,000 \mu \mathrm{g}$ per $100 \mathrm{ml}$ of plasma are present immediately after an infusion. These values are approximately 400 times the physiological levels of plasma iron.

The effect of free ionic iron in iron-dextran on plasma unsaturated iron-binding capacity should be most obvious in conditions in vitro, where the physiological mechanisms for the removal of iron from plasma are not available. The fact that there was very little alteration in the unsaturated ironbinding capacity in vitro is an indication both of the stability of the overall complex and the absence of significant transfer of iron.

Recent studies in vitro on the kinetics of iron binding by transferrin (Bates, Billups, and Saltman, 1967) have shown a definitive transfer of iron from a chelating agent to the metal binding sites in human transferrin. The rate of this transfer is a function of the chemical nature of the complexing agent and appears to be regulated by steric factors. The major component of iron-dextran is probably a ferric dextran complex and a similar transfer of iron to transferrin could take place. However, due to its relatively large molecular size (Ricketts, Cox, Fitzmaurice, and Moss, 1965), in comparison with the size of the ferric chelates used in the kinetic studies, it is probable that steric factors play an even more important part in limiting the transfer of iron. In a series of kinetic studies, iron-dextranwas shown to transfer its iron very slowly to the $\frac{-}{\circ}$ iron-binding protein. There was practically now transfer of iron at equivalent concentrations $\left(10^{-4} \mathrm{M} \widehat{\widehat{\nabla}}\right.$ binding equivalents of protein) and with higher $\stackrel{\circ}{\circ}$ concentrations of iron-dextran less than $20 \%$ of the binding sites on the transferrin were filled even $\overrightarrow{0}$ after 12 days (Saltman, 1967).

The rate of clearance of iron-dextran from the ${ }_{\sigma}^{\omega}$ plasma shows considerable variation amongst the species investigated and most probably reflects the different efficiencies of the reticuloendothelial $-{ }_{-}^{-}$ systems in their ability to phagocytize the irondextran. The plasma iron values remain high for $\overrightarrow{-}$ several hours after an injection or infusion but in spite of this there is no evidence of saturation of the unsaturated iron-binding capacity. The dogs $\operatorname{did}_{\mathrm{c}}$ show a slight fall immediately following the rapid $\mathbb{\mathbb { D }}$ injection of iron-dextran which might be due to the small amount of loosely bound or free ionic iron $\bar{\sigma}$ present. However, this cannot be the complete $\stackrel{\mathbb{D}}{-}$ explanation as the rabbits given a similar injection $\vec{\bullet}$ showed no fall in unsaturated iron-binding capacity. In the human patients the introduction of irondextran into the plasma was much slower and anyo small amount of ionic iron could be cleared by the normal physiological mechanism, with no problem of saturation of the unsaturated iron-binding $\frac{0}{\circ}$ capacity. The results have shown that there is very little alteration in the unsaturated iron-bindingō capacity value after total dose infusion.

Apart from the ionic iron content, the stability of iron-dextran in plasma is critical, as any breakdown involving the release of only $0.5 \%$ of the totato iron would completely saturate the unsaturated iron-ibinding capacity. Although this technique has now been used in many thousands of patients, there is no clinical evidence of any breakdown of the complex and no indication of toxic effects due too excess ionic iron. Reactions have been reported in? a small number of cases after the use of thiso technique but these have been of a hypersensitivity nature. The studies in vivo reported here haveos confirmed that no breakdown does occur, and that the unsaturated iron-binding capacity is notN saturated.

We thank Miss P. A. Walker, consultant obstetricianc and gynaecologist, and Dr K. W. Hancock, registrar, Wythenshawe Maternity Hospital, and Dr G. Walters, consultant pathologist, New Cross Hospital, Wolverhampton, for providing blood samples from patients and also $\mathrm{Mr} \mathrm{P}$. Hulme for his assistance with then experimental work. 
We wish to also thank Professor P. Saltman for his helpful comments and encouragement.

\section{REFERENCES}

Barber, A. A., Dempster, C., and Anderson, N. G. (1963). Clin. chim. Acta, 8, 143.

Basu, S. K. (1963). Lancet, 1, 1430.

Bates, G. W., Billups, C., and Saltman, P. (1967). J. Biol. Chem., 242, 2810.

Birdsall, N. J. M., Kok, D'A., and Wild, F. (1965). J. clin. Path., $18,453$.
Bonnar, J. (1965). Brit. med. J., 2, 1030.

Cox, J. S. G., King, R. E., and Reynolds, G. F. (1965). Nature (Lond.), 207, 1202.

Dawson, D. W., Goldthorp, W. O., and Spencer, D. (1965). J. Obstet. Gynaec. Brit. Cwlth, 72, 89.

Fielding, J., and Smith, G. M. (1963). J. clin. Path., 16, 12.

Golberg, L. (1958). In Iron in Clinical Medicine, p. 74, edited by R. O. Wallerstein and S. R. Mettier. University of California Press, Berkeley, California.

Kok, D'A, and Wild, F. (1960). J. clin. Path., 13, 241.

Marchasin, S., and Wallerstein, R. O. (1964). Blood, 23, 354.

Ricketts, C. R., Cox, J. S. G., Fitzmaurice, C., and Moss, G. F. (1965). Nature (Lond.), 208, 237.

Saltman, P. (1967). Personal communication. 